\title{
Mineração
}

\section{Financial guarantee for mine closure}

Hernani Mota de Lima

Professor do Departamento de Engenharia de Minas - DEMIN/EM/UFOP - E-mail: hernani@demin.ufop.br

Flávio Luiz da Costa

Robson Peixoto

Valdecy Caldeira

Mestrandos do Programa de Pós-Graduação em Engenharia Mineral do DEMIN

\section{Resumo}

Esse artigo trata das questões envolvendo a determinação do valor de uma garantia financeira para fins de fechamento de mina, os instrumentos de garantia disponíveis no mercado, suas características, vantagens e desvantagens, bem como trata dos problemas enfrentados pelas empresas de mineração e agências governamentais para implementação destes instrumentos.

Palavras-chave: garantia financeira, fechamento de mina.

\section{Abstract}

This paper deals with the determination of the amount of a closure guarantee, the most common financial instruments available to the mining companies to satisfy the regulatory agencies' current and anticipated requirements, characteristics, advantages and disadvantages pertaining to these instruments as well as the problems faced by mining companies and governments to implement such instruments.

Keywords: financial guarantee, mine closure. 


\section{Introduction}

Increasingly, financial guarantees tend to be required for new mining operations to ensure sufficient funds for mine closure and post closure purposes. Similar guarantees are also being gradually required for mining companies already in operation. These guarantees are prescribed conditions of exploration and mining titles and are generally referred in the Mining Acts in relation to exploration licences, assessments leases and mining leases. Such empowering legislation was developed mainly in response to an accumulated legacy of derelict mined-out land and long-term environmental liabilities (Marcus, 1990; Miller and Eldon, 1991; Miller, 1998; Da Rosa, 1999).

Financial guarantees are quite separate from any internal accounting provision for mine closure and should not in anyway counterbalance this provision. Financial guarantee is an instrument issued by a bonding company, an insurance company, a bank, or other financial institution (the issuer is called the "surety"), which agrees to hold itself liable for the acts or failures of a third party (Hayes, 1994). Financial guarantees are designed to protect the community from closure liabilities. Financial guarantee for mine closure and post closure is simply a guarantee that the closure plan will be implemented. It is for expected costs only (Miller, 1998; Da Rosa, 1999).

\section{Determination of the amount of a closure guarantee}

A closure plan serves as the basis for regulatory agencies' determination of the amount of the financial guarantee. A guarantee should reflect the cost of a mine closure and be adjustable, up or down, to reflect changes in the proposed closure plan. This cost will frequently be higher than the cost to the title holder, because, in the event of default by the operator, the state will not be able to use site's mine production equipment and personnel, with resulting marginal cost
(Hollands, 1999). In practice, however, according to Nazari (1999), permitting agencies in the U.S. have commonly underestimated closure costs by failing to account adequately for permit violations, off-site pollution, administrative costs and inflation.

Both government and mining companies, in every instance, need a detailed estimate of what it will cost to perform all required closure activities. Such estimate must be as accurate as possible since it will, in effect, form the basis for determining which instrument of providing financial guarantee are actually available to a given mining company. In preparing closure costs estimates, mining companies should determine the cost of rehabilitation at a time when the extend and manner of a mine's operation would make closing the mine components the most expensive. Government estimates should also consider the cost of hiring a third party to perform closure activities. In doing so, both government and industry will have anticipated the worst-case scenario.

In US the Department of Interior's Office of Surface Mining and

Table 1 - Closure Guarantee Factors, after Legislative Audit Division (1997).

\begin{tabular}{l|l}
\hline Direct closure costs & $\begin{array}{l}\text { Calculated using conditions which represent } \\
\text { the maximum closure cost. }\end{array}$ \\
\hline Indirect closure costs & $\begin{array}{l}\text { Contract preparation and administration costs } \\
\text { for staff time. Calculated by project staff and } \\
\text { site specific. }\end{array}$ \\
\hline Mobilization & 1 to 5 percent of direct closure cost \\
\hline Contingencies & $\begin{array}{l}\text { Project uncertainties and unexpected natural } \\
\text { events, } 2 \text { to } 5 \text { percent of direct closure costs. }\end{array}$ \\
\hline Engineering and Design & $\begin{array}{l}\text { Redesign to reflect current conditions, } 2 \text { to } 10 \\
\text { percent of direct costs. }\end{array}$ \\
\hline Profit and Overhead & $\begin{array}{l}\text { Contract profit and overhead not included in } \\
\text { direct cost calculations, } 3 \text { to } 14 \text { percent of } \\
\text { direct closure costs. }\end{array}$ \\
\hline Closure management & $\begin{array}{l}\text { Project inspection and supervision, } 2 \text { to } 7 \\
\text { percent of direct closure costs. }\end{array}$ \\
\hline
\end{tabular}

Reclamation (OSMR) has prepared a handbook on bond calculations that recommend determining closure bond amounts using the "greatest estimated closure costs for the permit term". According to an auditing report from the Legislative Audit Division of Montana, US closure guarantee calculation should also include costs factors as presented in Table 1.

\section{Financial guarantee instruments}

Financial guarantee instruments may be, and are, chosen from a large number of options. Each specific instrument may be appropriate in a given situation or set of circumstances, depending upon the financial strength of the mining company, its history of environmental performance ("track record"), the extent of the potential environmental liability and the time frame over which the liability is to be extinguished. An excellent guide to the economic consequences to companies of various bonding alternatives can be found in Hayes (1994). 
Miller (1998) and Anderson (1999) examined the various mechanisms of financial guarantee as well as the circumstances that influence the selection of these. The findings stress the importance of flexibility in the selection and application of the various types of bonding. However, in both studies there was no recommendation for one preferred instrument that could be a universal model. Table 2 summarises the characteristics, advantages and disadvantages of some of these instruments.

In the past, surety bonds were the most heavily instrument. However, currently there are few surety companies willing to underwrite bonds with closure requirements - an indication of the perceived risks involved. After the $11^{\text {th }}$ September of 2001 terrorist attack and bankruptcy process of big companies as ENRON Corporation, many of the security companies have declined to work with mining closure guarantees because of the highest risk involved (Carlton, 2002). This scenario has been previously anticipated by Belsky (1992), which stated that mining companies will face problems to get financial surety for mine closure purpose. Surety companies are becoming more selective in their choice of clients. This implies higher premiums, higher collateral requirements, narrower coverage and low aggregate bonding limits for individual mining.

In addition, new regulations have required extensive work to be done in order to properly close a mine and, as a consequence, closure costs are on the upswing. As closure costs rise, so do required financial guarantee limits. And as bonding limits rise, the ability of both surety and mining companies to meet financial guarantee requirements diminishes. As a consequence, mining companies in the US are to pushing governments in accepting self-guarantee based on company's assets.

Financial guarantee are costly for smaller and medium mining companies. In the US, there is a bond pool programme that enables these companies to post financial guarantees without incurring prohibitive costs. Bond pools are designed to pay for closure costs incurred by pool members, in case of bankruptcy or other unexpected events that affect the capacity of a firm to fulfil closure commitments. Membership of bond pools is voluntary. An admission test typically includes: compliance records and number of permit violations; years of operation; and rehabilitation experience. Following admission, members may be categorised according their "risk" which they bring into the pool. According to Danielson and Nixon (1999) and Anderson (1999) bond pools have not been successful in the US because of the risks involved. One of the many risks results from a mining company or operator joining the bond pool, paying a minimal amount, and then declaring bankruptcy or disclosing a serious environmental problem.

The mining industry, however, should require that governments specify an approved selection of financial guarantee instruments and discuss with companies which instruments are most appropriate to the specific closure situation. The choice of an instrument should recognise the age and duration of the total obligation, what has been spent to date and the relative risk of default.

The different instruments should be distinguished on the basis of such circumstances as the following:

Soft guarantees (e.g. corporate guarantee) can be used where the risk of default is low; the closure plan and cost estimate is independently confirmed (i.e. the technical risk is low); the closure is of a short-term nature; and the company has appropriate financial strength to support the guarantee, such as an investment grade rating (Miller, 1998).

Hard guarantees (e.g. letters of credit, trust funds) can be used where the risk of default is high; the timing of the closure is imminent; the closure must be continued over the very long term and the company does not have an investment grade rating (Miller, 1998).

\section{Financial guarantee implementation}

The problems of implementing financial guarantees for mine closure include: governments' lack of familiarity with the use of financial surety; delays and high legal costs; lack of consistency across provincial/state governments with respect to the choice of financial surety instruments; absence of guidelines for applying the concepts of discounting, long-term obligations and calculating the amount of security required; unwillingness of government to recognise that a "softer" form of assurance may be appropriate in certain circumstances; and lack of equitable tax treatment of funds when funds are actually deposited for this purpose (Miller, 1998).

Financial guarantee, as an economic instrument, must be complemented by permitting, inspection, enforcement and education process to be effectively implemented. Permitting process it is necessary for clarifying the criteria for mine closure, impelling planning for closure from the outset of mine planning and successfully ensuring enforcement of closure criteria. The enforcement capacity of the regulator should be clearly and explicit defined since it allows all parties involved to be aware of the implications for the financial guarantee in case of permit violations or bankruptcy. Inspections require good communication between mining companies and regulators with the goal of identifying faults in the previous closure plan and problems during their formative stages (Anderson, 1999).

Table 3 presents the principles that should be followed for governments for developing and implementing a financial guarantee policy for mine closure.

\section{Conclusion}

Rehabilitation of a mine site mainly happens as part of the closure phase and, clearly, achieving a satisfactory outcome is dependent upon the operator still being able to manage and fund appropriate works. Financial guarantee 
Table 2 - Financial Guarantee Instruments.

\begin{tabular}{|c|c|c|c|}
\hline Types & Characteristics & Advantages & Disadvantages \\
\hline $\begin{array}{l}\text { Surety } \\
\text { bonds }\end{array}$ & $\begin{array}{l}\text { - Most heavily used instrument. } \\
\text { - Used for at least two decades in } \\
\text { US. } \\
\text { - A premium is paid by the mining } \\
\text { company to the underwriting } \\
\text { institution that is the guarantee. }\end{array}$ & $\begin{array}{l}\text { - The cost of getting it is relatively } \\
\text { low. } \\
\text { - Cost associated with putting it are } \\
\text { expensed as a tax deductible item. } \\
\text { - Once in place only a minimal } \\
\text { amount of administration is } \\
\text { required. } \\
\text { - Many ways of initiating and } \\
\text { releasing bonds trough phased } \\
\text { implementation and phased } \\
\text { release. }\end{array}$ & $\begin{array}{l}\text { - Often a Letter of Credit is required } \\
\text { to back up the bond, which makes it } \\
\text { more expensive. } \\
\text { - Its availability may be restrict by a } \\
\text { company's credit and its } \\
\text { environmental risk. } \\
\text { - The full face value of the surety } \\
\text { may be required. }\end{array}$ \\
\hline $\begin{array}{l}\text { Letters of } \\
\text { Credit }\end{array}$ & $\begin{array}{l}\text { - Similar to a surety bond. } \\
\text { - The content of a LC should reflect } \\
\text { the terms and conditions agreed } \\
\text { between a company and the } \\
\text { government with respect to a } \\
\text { specific closure plan. }\end{array}$ & $\begin{array}{l}\text { - Low initial cost (about } 1 \% \text { per } \\
\text { annum of the face value). } \\
\text { - Cost associated with opening a } \\
\text { LC are expensed as a tax } \\
\text { deductible item. } \\
\text { - Once in place only a minimal } \\
\text { amount of administration is } \\
\text { required. }\end{array}$ & $\begin{array}{l}\text { - Issued by a bank and usually for a } \\
\text { larger sum of money than originally } \\
\text { estimated for closure. } \\
\text { - Fee paid to the lending institution } \\
\text { to cover the transaction (even if } \\
\text { draw-down does not occur). } \\
\text { - The availability of a LC may be } \\
\text { restrict by a company's credit and } \\
\text { its environmental risk. } \\
\text { - Issued for a period of one year - } \\
\text { short-term solution for a long-term } \\
\text { problem. } \\
\text { - Reduction of the company } \\
\text { borrowing power. }\end{array}$ \\
\hline $\begin{array}{c}\text { Cash Trust } \\
\text { Funds }\end{array}$ & $\begin{array}{l}\text { - The funds must be structured in } \\
\text { such a way as to give reasonable } \\
\text { assurance that sufficient funds will } \\
\text { be available to meet expected } \\
\text { closure costs. } \\
\text { - It is highly desirable that the } \\
\text { income earned by the fund be tax } \\
\text { protected until it is withdrawn. }\end{array}$ & $\begin{array}{l}\text { - The company has control over its } \\
\text { fund, since any surpluses created } \\
\text { or earned should be returned to the } \\
\text { company; } \\
\text { - The company have the incentive } \\
\text { to ensure sound management of } \\
\text { the fund; } \\
\text { - Are more visible and often better } \\
\text { understood by government and the } \\
\text { public than other alternatives. }\end{array}$ & $\begin{array}{l}\text { - Great uncertainty about the size of } \\
\text { the fund in view of the long time } \\
\text { frame involved; } \\
\text { - If large amount is required a } \\
\text { transition period is necessary to } \\
\text { allow time to the company to build } \\
\text { up the required financial guarantee. }\end{array}$ \\
\hline
\end{tabular}

Continuação... 


\begin{tabular}{|c|c|c|c|}
\hline Types & Characteristics & Advantages & Disadvantages \\
\hline Insurances & $\begin{array}{l}\text { - Special form of surety bond. } \\
\text { - The premium paid will be a } \\
\text { function of the estimated closure } \\
\text { cost with actuarial calculations to } \\
\text { annual pay-out levels and the total } \\
\text { amount of the insurance. }\end{array}$ & $\begin{array}{l}\text { - May require smaller up-front cash } \\
\text { commitments than a cash trust } \\
\text { fund. } \\
\text { - Premiums would be tax } \\
\text { deductible. } \\
\text { - Less administration is required } \\
\text { than with a cash trust fund. }\end{array}$ & $\begin{array}{l}\text { - Initial premiums may be very high } \\
\text { to ensure substance of the } \\
\text { insurance. } \\
\text { - In addition to premium amounts } \\
\text { there could be taxes and insurance } \\
\text { brokerage fees. } \\
\text { - A new, not well tested guarantee } \\
\text { instrument. }\end{array}$ \\
\hline $\begin{array}{l}\text { Self- } \\
\text { guarantees }\end{array}$ & $\begin{array}{l}\text { - Also known as corporate } \\
\text { guarantee or self-insuring. } \\
\text { - Based on an evaluation of the } \\
\text { assets and liabilities of the } \\
\text { company and its ability to pay the } \\
\text { cost of closure requirements. }\end{array}$ & $\begin{array}{l}\text { - Financial instrument of choice for } \\
\text { a mining company. }\end{array}$ & $\begin{array}{l}\text { - Require long history of financial } \\
\text { stability and an annual financial } \\
\text { statement prepared by accredited } \\
\text { accounting firm. } \\
\text { - Gaining access to assets may be } \\
\text { problematic in the case of firms } \\
\text { facing bankruptcy. }\end{array}$ \\
\hline
\end{tabular}

Source: (Miller, 1998; Anderson, 1999)

provides security to the state should the operator default and is designed to protect the community from closure liabilities.

Government agencies in a number of countries have adopted policies that require mining companies to provide financial guarantee for mine closure purposes. Financial guarantee provides insurance that rehabilitation plans will be completed should the proponent fail because of premature closing, financial default or other causes. In systems that require financial guarantee, the cost of maintaining the guarantee and the advantages of lowering or terminating it are considered strong incentives for companies to begin the closure programme and to follow it in every detail.

\section{References}

ANDERSON, K. Using financial assurances to manage the environmental risks of mining projects. Environmental Policy in Mining: Corporate Strategy and Planning for Closure. In: WARHURST, A., NORONHA, L. (ed.). London: Lewis Publishers, 1999, p.283-293.
Table 3 - Financial Guarantee Principles, after Da Rosa (1999)

\begin{tabular}{c|l}
\hline Closure costs & $\begin{array}{l}\text { Financial guarantees must cover the mine } \\
\text { company's costs, both rehabilitation and the post- } \\
\text { closure monitoring period. }\end{array}$ \\
\hline Liquidity & $\begin{array}{l}\text { All forms of financial guarantee should be } \\
\text { reasonably liquid. }\end{array}$ \\
\hline Accessibility & $\begin{array}{l}\text { Financial assurance should be readily accessible, } \\
\text { dedicated and only released with the specific assent } \\
\text { of the regulatory authority, so that regulators can } \\
\text { promptly obtain funding to initiate proper closure in } \\
\text { case of operator default. }\end{array}$ \\
\hline Pealthy guarantors & $\begin{array}{l}\text { Regulators must carefully screen guarantors' } \\
\text { financial health before accepting any form of } \\
\text { assurance. }\end{array}$ \\
\hline No substitute & $\begin{array}{l}\text { Any financial guarantee should not be regarded as a } \\
\text { surrogate for a company's legal liability for mine } \\
\text { closure. } \\
\text { opportunity to comment both before the setting of a } \\
\text { bond amount and before any decision on whether to } \\
\text { release a bond. }\end{array}$ \\
\hline
\end{tabular}


BELSKY, E. Factors affecting economic risks in mining: Focus on pollution insurance and bonding. Risk Assessment/Management Issues in the Environmental Planning of Mines. In: VAN ZYL, D., KOVAL, M., LI T. M. (ed.). Littleton, CO, Society for Mining, Metallurgy, and Exploration, Inc., 1992. 143-147.

CARLTON, J. Financial surety creats crise for mining companies. The Wall Street Journal, 23/07/02.

DA ROSA, C. Financial planning for mine closure. Mining Environmental Management. v. 7, n. 2, p. 10-13. 1999.

HAYES, C. Reclamation accounting and practical considerations in funding reclamation obligations. Rocky Mountain
Mineral Law Institutes. v. 9, n. 40, p. 9.19.32, 1994

HOLLANDS, K. Security deposits in NSW. Mining Environmental Management. v.7, n. 2, p. 17-18, 1999.

LEGISLATIVE AUDIT DIVISION. Review of hard rock mining reclamation bond requirements. Legislative Audit Division, Montana. December 4, 1997, 9.

MARCUS, J. Mining environment - Financial assurances for mine closure - A discussion of the issues. E\&Mj-Engineering and Mining Journal. v. 191, n. 8, E16-\&, 1990. MILLER, C. G., D. ELDON. Financial assurance for mine reclamation, decommissioning and post-closure obligations. In: INTERNATIONAL CONFERENCE ON
THE ABATEMENT OF ACIDIC DRAINAGE MONTREAL, 2. Montreal, Quebec: Environmental Drainage Program 1991. p. 127-143.

MILLER, G. C. Use of financial surety for environmental purposes. Book downloaded on 28/02/1999 from http:// www.icme.com/icme/finsurety.htm. International Council on Metals and the Environment (ICME): v. 55. 1998.

NAZARI, M. Financial provision for mine closure. Mining Environmental Management. v. 7, n. 3, p. 14-15. 1999.

Artigo recebido em 26/05/2003 e aprovado em 11/09/2003.

\section{Você não vai esconder seu trabalho de anos de pesquisas numa revista que nunca se sabe quando vai ser publicada, ou que ninguém lê... Vai? \\ Em janeiro de 2003 a REM completou 67 anos.}

\section{6 - 2003 \\ Conheça e \\ Publique-o na REM \\ 67 anos divulgando ciência.}

